\title{
NEW FRONTIERS IN RESOURCE TECHNOLOGY - A LEGAL OVERVIEW
}

\begin{abstract}
Three Alberta lawyers, representing different corporate entities in the oil and gas industry, discuss the approach to and treatment of technology developed in relation to oil sands, heavy oil and frontier exploration activities. Part One provides an introduction to some of the legal challenges created by new developments in resource technology, and examines the experience of Petro-Canada in its frontier operations. Part Two focusses upon the Syncrude project, and the unique problems to which it has given rise. Part Three discusses the role of the Alberta Oil Sands Technology and Research Authority.
\end{abstract}

\section{PART ONE}

\section{R. PETTIGREW*}

\section{INTRODUCTION}

These papers deal with an overview of resource technology, development and use in today's oil and gas industry. The authors provide this overview by sharing their experiences, opinions and views, which although all legally orientated arise from different backgrounds, work experiences and policy considerations. It is hoped that the blending together of these different approaches gives a more complete picture of the topic.

The oil and gas industry in Canada, as throughout the world, has in recent years changed dramatically, shifting its primary emphasis of activity from finding and producing conventional sources of hydrocarbons to exploring and developing what are generally classified as frontier regions or frontier sources of oil and gas. These include oilsands, heavy oil, shale deposits, Arctic ice regions, secondary recovery, deepwater hostile environment areas, solar energy, nuclear energy, tidal power and wind power.

As a result of this shift in emphasis, resource lawyers have experienced a coincident change in their work. At one time, the practising oil and gas lawyer could draw from his precedent books a standard farmout agreement, a standard operating agreement and a standard royalty agreement together with a smattering of surface leases, roadway easements, pipeline easements and the odd license to use; and armed with these documents, he could expect to handle ninety percent or more of his expected assignments. Today, al. though the standard precedents continue to be widely used, the percentage of work which can be accomplished by using these forms has diminished. The exploration and production work in which most oil companies are involved today dictates the need for unique legal documents to express the relationships and associations being created. The so-called "mega projects" offer a much different environment within which a lawyer works, and constantly call for creative and innovative draftsmanship. In addition, because of the magnitude and cost of these projects, the number of parties involved in any particular venture balloons from two or three which was common in the past, to eight and nine and sometimes even more companies. Endeavouring to structure agreements which accommodate the differing policies and interests of such large groups demands increased skills from our lawyers and legal departments.

The changing environment in the oil and gas industry has also affected resource technology, and has or should affect the manner in which lawyers deal with such technology.

- Sulicitor, Petru-Canada, Calgary, Alberta. 
How many lawyers' precedent books contain a form of licensing agreement, technology royalty agreement or technology use and exchange agreement? There are probably lim. ited numbers of these kinds of documents, because most oil and gas lawyers in Western Canada often farm out matters of technology to patent agents and patent attorneys. Therefore it is a basic premise of this paper that today's oil and gas lawyers need to develop an increased awareness of resource technology issues, because the subject is taking on a considerably higher profile than in the past, a profile which arises directly from the industry's move toward frontier exploration and development.

Without doubt, the technology to drill a well, transport oil or natural gas and refine oil into consumable products is old and well proven. However, the technology picture with respect to new frontier activities is not 80 simple because in these projects industry cannot purchase from the shelf any, or in some cases all, of the required technology. In most frontier projects, the proponents start with a base of existing and proven technology or technologies. It is, however, known or quickly realized that such technology requires modification and change because:

1. the technology adopted is usually put to work in an environment which is substantially different from that in which it was originally proven. The term environment in this contert includes such things as the actual, physical weather environment within which the technology must perform, the scale or size of the units to which the technology is applied and the character of the hydrocarbon resource upon which the technology must work; and

2. rather than representing the total amount of technology required to complete the project, in most cases each piece of base technology constitutes only one part of the technology required for the job. Consequently, each piece is expected to fit and operate within a system of other technologies, each of which may be unrelated to the base technology.

Accordingly, in many frontier projects new technology is developed by the project owners as they proceed through a system of problem solving and innovation whereby the existing base technology is modified, improved upon or totally changed to meet a different application, a changed environment or a changed mode of operation from that in which the base tochnology was originally tested or proven.

As a consequence, the oil industry's role in technology development is significantly increasing. The experience of Syncrude Canada Ltd., dealt with later, is a perfect example of this. Syncrude is not just a mining process, an extraction process or an upgrading process. It is all of these things put together and functioning in one homogenous system. Although Syncrude technology began with proven know-how and information, it has changed and grown significantly because of many thousands of hours of work by engineers, administrative and field workers who have had to solve problems in the basic technology which were hampering maximum output from the Project. This type of technology cannot be bought from the shelf. It is learned and developed over time, not in the laboratory but in the field.

Not only has frontier activity led the oil industry to assume a greater role in technology development; but in addition, such activity has resulted in a change in the focus of such development. Most major oil companies have had established research and development operations for years. Such operations, however, have been devoted principally to refining and developing for the consumer market better oil and gas products which would provide, for example, greater octane in gasoline, more BTU output in natural gas, more petro-chemical uses. Historically, such departments have not been involved in the more fundamental examination of how one actually extracts the resource from the ground. and, in the case of synthetic crude oil from oilsands or heavy oil, how one upgrades the resource to create a marketable commodity. These questions are the ones most often asked by an oil company embarking on a frontier project because they address the fundamental issue of whether one can technically and economically obtain the resource at all. Furthermore, from past experience oil companies are more aware of the need for new and 
innovative technology, because technology or sufficient technology does not exist for use within the project or the project requires a unique application of developed technology. Accordingly, more and more emphasis is being placed upon developing extraction and upgrading technology rather than developing technology for expanding or bettering resource end uses. Recent efforts to develop new enhanced and secondary recovery methods of obtaining crude oil are a good example of this situation.

Finally, it should be noted that the cost of technology development, as a result of frontier oil and gas projects, has increased many times over that of the past. Not only must oil companies pay the price to acquire base technology for their projects, they must also pay the price in terms of dollars and cents and man-hours expended to improve upon, modify or totally change this base technology to meet its new application. Furthermore, new technology thus developed may be site specific in that it has been designed to accommodate a particular frontier situation or type of hydrocarbon resource, and may or may not be applicable for sale to the owners of other projects. The absence of an assured market for new technology thus may create an asset to which millions of dollars have been applied but which on a stand alone basis may not be able to generate a return.

For these reasons, technology development has become a key element of oil company work. Lawyers must recognize this and make a conscious effort to respond to the issues being generated as a result. This cannot be accomplished by merely ensuring that the standard technology provisions and secrecy provisions are present in agreements, because frontier oil and gas activity creates a new scenario which requires new and innovative approaches.

Consider the situation where a group of project owners licenses a base technology which is expected to be and in fact is subsequently modified and/or improved upon. What are the rights of the project owners with respect to owning the improvements to the technology and with respect to using and disseminating the new technology? What are the rights of the licensor with respect to ownership of this new technology and its usage and dissemination? Do these rights change if the modifications or changes were the result of the combined effort of both the owner group and the licensor? How does the owner group ensure that such modifications or changes are in fact identified as being new technology advancements, particularly if the modification or change stems from field workers merely resolving an operational problem and being unaware that they have developed a new piece of technology?

Consider also the situation where a group of project owners retains a consultant to review the technology situation as it may or may not apply to the frontier project being pursued. In addition to determining who owns the newly developed technology and determining what rights the owners and the consultant may claim to the use of such tech. nology, what must the owners' group do to ensure that the consultant protects the confidentiality of the information generated? What type of infrastructure is required by the consultant and owner companies to ensure that information is kept secret and not "leaked" to third parties? Secrecy agreements, invention assignment agreements and the like abound throughout the oil industry, but practical experience shows that such agreements are difficult to apply and even more difficult to enforce.

Consider, finally, the situation where a group of project owners has ownership rights to newly developed technology. What should be the strategy of the owners' group with respect to patenting this knowledge? Should the knowledge not be patented, but rather maintained as closely held know-how or trade secrets? This question is often asked, but is not easy to answer.

Given this background, the following experiences, views and opinions are designed to portray how resource technology development is taking shape in an oil and gas industry which is moving into the frontier exploration and development field. First, reference will be made to the experiences of Petro-Canada in technology development, to illustrate some of the problems that can arise and the magnitude of the technology development activity by oil and gas companies. Second, the Syncrude experience will be examined, 
representing in many cases the first opportunity for the participants to encounter and deal with the technology development question as it relates to oilsands activities. Finally, the role of the Alberta Oil Sands Technology and Research Authority (AOSTRA) will be discussed. The latter part may raise questions respecting what attitudes the Government of Alberta has toward collaboration between industry and Government on resource tech. nology development, and the policy issue of whether there is merit in having a central clearing house of technology which can be used by Government and industry alike.

\section{THE PETRO-CANADA EXPERIENCE}

Petro-Canada's peculiar structure and mandate offers perhaps as well as any other major oil company in Canada, a useful, broad brush of experience in the resource technology development field.

\section{A. Syncrude}

Syncrude's experience is undoubtedly the key one to date in the area of oilsands development and operation. The sheer size of the operation, together with the fact that a unique mining operation needed to be coupled with a sophisticated extraction and upgrading process, hes resulted in the accumulation of an astounding amount of technology. Indeed, a flow chart representation of the technology picture prepared at Syncrude consumes almost fourteen (14) pages of standard size office stationery.

In addition to the volume of technology, its complexity is enormous. Coming to grips with how to deal with this technology has proven difficult and perhaps equally as complex. The initial problem of identifying a package or packages of technology which the Syncrude participants own and are entitled to sell has consumed many months of work, given rise to at least two legal opinions (with a third one on the way) and still remains unresolved to some extent. In addition, there have been various views in the owner group pertaining to the more fundamental question of what is materially gained or materially lost in endeavouring to deal with the technology at all. The views of the Syncrude owner group extend all the way from total free disclosure of the technology to all outside persons 80 that general benefit can be derived from the Syncrude knowledge, to suggesting that the marketing of Syncrude technology holds the promise of returns so small in relation to the overall size of the project itself that spending time now in attempting to reach a setisfactory consensus on the matter is non-productive.

These problems have provided a learning experience for those involved. Some of the insights that have been gained include:

1. The Syncrude Project has resulted in the generation of substantial amounts of new technology which, if to be at all beneficial in its own right to the owners, needs to be carefully identified and catalogued as early as possible following its creation. Such identification and cataloguing can only effectively take place through the vehicle of a carefully planned monitoring and recording system designed to meet this specific task. Lawyers can and should be called upon to play an important role in assisting and advising on the formulation and creation of such a system.

2. The technology associated with and used in a frontier project will often consist of a base technology primarily licensed from third party licensors, along with new technology developed by or for the owners of the project. The former type of technology will likely carry with it restrictions on use so that the project owners cannot use the technology outside the project itself. The latter type of technology should, subject to sometimes extensive negotiations with third party licensors, be owned by the project owners, and be available for subsequent dissemination by them with a view to earning a return. The importance of maintaining a distinction between these two types of technology is clear, but this task is difficult as the two types of technology are usually interrelated. The Syncrude experience has made the project owners aware of the difficulty in keeping these technologies separate, and suggests that considerable time should be spent by the project staff and lawyers in monitoring and distinguishing between new technology and licensed technology. 
3. The important time at which to consider the issue of technology, and how technology developed and owned as a result of the project may be subsequently used and dis. seminated, is when the proponent companies first gather to contemplate the basic principles and understandings of their association. This suggestion may appear obvious. However, experience has shown that the effort required at the outset to come to grips with this question is not being expended. As a consequence, several years later, the owners may have differing perspectives on what to do with the technology they own. Such differences can result in delays and missed business opportunities. Accordingly, these issues should be faced at the outset of any project, and a common understanding achieved that gives each owner the proportionate degree of freedom and restriction to use newly developed and owned technology in an internally beneficial way, but nevertheless in a way which generally benefits the total project and its owners.

Finally, the Syncrude Project has made its owners more aware of the difficulties of maintaining the confidentiality of proprietary technology. The owners recognize that a significant amount of Syncrude Technology is held in the minds of its staff, and problems may arise when some of this staff is lured to other oilsands mining projects.

\section{B. The Proposed Alsands Project}

This concern has become more obvious with the announcement of the proposed Alsands Project in which Petro-Canada is a participant. Alsands has proposed constructing an oilsands mining, extracting and upgrading facility similar to that of Syncrude and Suncor, which to a great extent will be based upon technolozy developed and demon. strated in the Syncrude and Suncor operations. At this point, technology exchange agreements do not exist between the owners of the Alsands Project and the Syncrude participants; and this situation has created certain difficulties for the participants in both projecte.

Petro-Canada personnel have often been constrained from effectively participating with the other owners of the Alsends Project in discussions on matters of technology, including what particular technology or technologies should be employed. Our personnel exercise extreme caution in dealing with other Alsands owners so as not to overstep the bounds of their technology non-disclosure obligations with the Syncrude participants. Management and engineers ask how far they may 80 in discussing confidential technolOgy with the Alsands Group. To be safe, perhaps they should say nothing at all. This solution prevents the staff from contributing usefully to the Alsands discussions, but points out the need for lawyers to ensure that their companies or clients have the freedom under project agreements to deal with new technology in a way which is consistent with their future policy aspirations and work programs. Similar problems have been experienced in relation to Petro-Canada's and Alberta Gas Trunk Line's recently announced fourth oilsands mining project.

\section{The Arctic Pilot Project}

The Arctic Pilot Project being undertaken by a consortium of companies involving Petro-Canada offers another example of how frontier projects have changed the course of resource technology development. The Arctic Pilot Project involves oil companies and shipping companies working together to develop an Arctic transportation system of moving natural gas from the high Arctic regions of Canada to southern markets. The Arctic Pilot Project encompasses a system of many technologies: finding and gathering gas in a remote Arctic region, liquefying this gas on barge-mounted liquefaction units, transporting it in massive LNG tankers through the Arctic waters, and regasifying it at a southern terminal for transportation to market. Technology respecting liquefaction of natural gas, transportation of LNG via huge LNG carriers and regasification of natural gas has long been established and proven; however, the Arctic Pilot Project demands that these separate technologies work together in an overall system while operating in an environment completely different from that ever before experienced. 
The Arctic Pilot Project demonstrates the oil industry's commitment to intensive technology development activities, and this frontier endeavour may result in a whole new chapter in the book of technology with respect to resource extraction, handling and transportation methods in the high Arctic. The lawyers representing the project participants have expended substantial time and effort in determining what rights each owner will have to the subsequent usege and disclosure of the technology. This issue is complicated by the fact that the participant group includes a shipping company which looks upon the marine technology with an interest differing from that of the oil companies. However, these challenges are being worked through.

\section{The East Coast}

The recent flurry of drilling and exploration activity on the east coast of Canada provides another set of new legal challenges. Notwithstanding the fact that much technology is already in existence respecting deepwater, hostile environment, drilling activity, the group of which Petro-Canada is a part has embarked on a major investigative study which will encompass some three years of work and several millions of dollars. This study is devoted to assessing the existing technolosy of deepwater drilling and determining its applicability to the Petro-Canada operation. In addition, the study is designed to examine all other possible technologies which can be used in the area, and to reach conclusions as to what technology can be best used off the east coast.

The magnitude of this study has given the lawyers much to consider. Current effort is being expended to ensure that the study manager has or establishes an adequate internal security system to protect the confidential information and technology which it is hoped the project will generate. It is also recognized that as the study grows, the owners will have to concern themselves about the security systems of all sub-consultants.

The lawyers involved recognize the technology review and evaluation study to be a significent commitment by the consortium partners, and recognize that the fruits of this oxercise should be treated as a valued asset of the project owners. This reinforces one of the basic views expressed in this paper, namely that lawyers ought to give matters of technolosy, particularly in relation to frontier oil and gas projects, more devoted effort and priority.

\section{E. Other Research}

As mentioned earlier, the focus of technology development appears to be changing, to emphasize techniques of acquiring and/or extracting resources rather than techniques of refining and upgrading extracted hydrocarbons. In this regard, the following activities of which Petro-Canade is a part are worth noting:

1. Petro-Caneda, together with four other oil companies, has embarked on a several year study program called the Mine Assisted In-Situ Project (MAISP) to assess and determine the technical and economic feasibility of a new in-situ heavy oil mining technique - horizontal drilling. It is hoped that this technique, if proven, can be employed on a commercial scale which will enhance the capabilities of oilsands operators to extract oil from the many already defined locations in the oilsands areas requiring in-situ mining techniques.

2. Petro-Canada, together with Canada Cities Service, Esso Resources Canada Ltd. and the Japanese Oil Sands Company, has embarked on a massive fifteen year study program to develop, among other things, technology which will be effective in ob. taining production from Alberta's oilsands and heavy oil deposits. Because this venture is heavily technology-development orientated, the parties have spent considerable time identifying the rights of the owners of the project to use and disseminate the information acquired. Significant work lies ahead as substantial technological developments arise and decisions need to be msde concerning their marketability and usage.

3. Petro-Canada and Nova, an Alberta corporation, have recently announced the formation of a joint venture to consider the technical and economic feasibility of building the fourth oilsands mining plant in the Athabasca oilsands area of northern 
Alberta. One of the expressed objectives of the joint venture is to expend several tens of millions of dollars in completely reviewing the current status of technology development in the oilsands field, including mining, extraction, and upgrading activities. The objective is to obtain the best possible and most advanced technology for use within the project.

Another project in which Petro-Canada has become involved stems from the fact that problems which exist in Canada exist elsewhere in the world. Through co-operative efforts, nations can together expend time, money and effort to solve problems and develop technology which is mutually beneficial. Petro-Canada has recently concluded arrangements with the Venezuelen Government oil corporation to embark on purely technology-development activities relating to upgrading processes for heavy oil. The vast deposits of heavy oil which exist in both Alberta and Venezuela present similar problems for process upgrading. The technology exchange agreement between Petro-Canada and the Venezuelan Government provides that each party will explore the technical and economic feasibility of different upgrading processes and provide information on the processes to the other party. As well, there is an exchange of technical people involved which provides each country's oil company with the opportunity of gaining a resident knowledge on the technology development work being undertaken.

Petro-Canada has also recently become involved in process development work as it relates to heavy oil upgrading technology. Although on its face this type of activity seems like natural work for an oil company, it is rather novel as most oil companies in Western Canada appear not to consider the pure technology development business to be a corporate objective. Such activities have historically been left to the Fluors, Lavalins, Lummuses, and UOPs of this world, who make their money by developing and marketing technology.

The legal difficulties arising from pure technology development work can be challenging. Oil companies, as intensive technology users, have flowing into their offices various processes and inventions which may or may not relate to work which the company is presently performing or contemplating. Each such process or invention is usually accompanied by a standard form of secrecy undertaking which may bind the whole company, or certain individuals in the company who will actually view the information. Once the secrecy agreements have been signed, lawyers may have to consider the following matters:

1. The company or client which has received the information must be careful not to breach its secrecy obligations. This may involve the lawyer in assisting to establish technology safeguard systems and controls within the company.

2. The difficulty of preventing unlawful dissemination of information is also a problem which becomes more complicated when the company or client itself gets involved in the development of competing technology. The company must ensure that individuals who have examined and are familiar with information on competing processes do not get involved in the development phase of competing technology on which the company is working. Defining the line which should not be overstepped can be a difficult task for the lawyer.

3. What is the company's liability or responsibility with respect to an employee who leaves the employ of the company and takes in his mind confidential information? As oil companies become more and more technology-development orientated, lawyers may be asked to resolve this question.

The activities and projects of Petro-Cansda, both actual and proposed, with respect to new resource technology development do not stop here. When one considers all the other companies engaged in similar activities and projects, such as Dome's work in the Beaufort Sea, Pan Arctic's work in the Aretic regions, and Esso's work at Cold Lake, a long list of examples could be easily compiled. However, it is hoped that these observations have illustrated the scope and complexity of resource technology development in relation to frontier oil and gas activities, and have raised some of the issues, questions and problems which may be encountered in the future. 


\section{PART TWO}

\section{J. C. BJORNSON**}

In this portion of the paper, the role of the solicitor in three general areas will be discussed:

1. the tar sands operator as the purchaser of technology;

2. the tar sands operator as a developer of technology; and

3. the tar sands operator as a seller of technology.

The discussion of the tar sands operator as a purchaser of technology will refer to license and related agreements which cover the technology necessary to build the basic units of a plant. In addition to these license agreements, there are many other arrangements in which the company requires technical information relating to mining, environmental concerns, and other supportive technology. The license agreement is, however, the vehicle under which one acquires the hard core technology for the plant.

In relation to the tar sands company as the developer of technology, matters discussed include how the company acquires technology and protects what it acquires as an owner and an operator of a plant.

The section on the tar sands operator as a seller of technology deals primarily with matters relating to trade secrets and know-how, which is a large part of the type of technology acquired by a tar sands operator. Matters relating to patent are not discussed. This does not suggest there is no patent activity. In fact, patenting patentable inventions generated in the plent and by our Research Department is a continuous activity.

\section{A. Taking a License}

\section{THE TAR SANDS OPERATOR AS A PURCHASER OF TECHNOLOGY}

One of the first decisions a client must make after deciding to proceed with construction of a tar sands plant is what process or combination of processes will be utilized in the proposed plant. Having made a decision on the basis of technical research and the advice of its consultants, the client will be disposed to select, in most instances, the technology being offered for license by licensors that has been proven the most effective and welldeveloped in the area. The main method by which such technology is ordinarily acquired is the process license afreement.

Although a license agreement may be either exclusive or non-exclusive, a developer of process technology, particularly in the tar sands area, will wish to license its process to several industrial users. Consequently, the grant of license will ordinarily be non-exclusive.

\section{B. The Grant}

In granting the right to use a certain process, a licensor will address the following issues.

1. The grant will most likely be a grant to use as distinct from a grant to use and sell, since the licensor will wish to retain absolute control over the right to sell its process to other users.

2. The licensor will, depending on the fees to be paid by the licensee, heve to determine whether or not the license is for use in a specific plant, that is, a plant license, as opposed to field license. A field license is one which may be utilized in any number of jlants by the licensee, whereas a plant license may only be used for the specific plant in question.

3. The right to use a specific process will no doubt be limited geographically even if a field license is granted to a particular area such as northeast Alberta or Canada.

-. General Counacl. Synerude Cenada Ltd.. Edmonton. Alberta. 
4. The licensor will also be inclined to restrict use of the process license which is to be used only "for the purpose of processing bitumen extracted from tar sands". The agreement should reflect the possibility that a shortage of bitumen as feed stock could occur; consequently, it is desirable to provide for intermittent use of other feed stock under such circumstances and to provide whether or not the royalty payable will be identical to that payable for the processing of bitumen extracted from tar sands.

\section{Consideration for the Grant}

Ordinarily, a process licensor will wish consideration for the grant to be paid by way of a lump sum paid-up license fee. It is naturally in the interest of the licensor that such paid-up license fee be paid as soon as possible, preferably prior to start-up of the plant in question. Although it is true that a licensor may wish to have the amount of its fee reflect the exceptionsl performance of the process, the licensor can accomplish this aim by negotiating additional fees for performance over defined volumes of production without affecting its ability to secure the majority of its license fee in advance of the start-up of the plant.

On the other hand, the licensee's interest is to delay payment of the paid-up license fee as long as possible in order to ensure that it has in its possession a certain portion of the license fee for a significant period of time following start-up of the plant. This will permit the licensee to determine whether or not the process guarantees granted by the licensor have been met; if such process guarantees are not met, the licensee will have in hand a certain portion of the license fee which would otherwise be due and owing by the licensee to the licensor.

\section{Confidentiality}

Few licensors would dispute the fact that in the licensing of process technology, licensing of "confidential technical information" is at lesst as important, if not more important, than the granting of "patent righte". Consequently, a process licensor will wish to ensure that any confidential information disclosed to a licensee is the subject of strict confidentiality obligations.

In turn, the licensee will require the ability to disclose the licensor's information on a need to know basis, to third parties, such as the licensee's contrector and its various subcontractors, consultants, and the like.

The process license agreement will usually incorporate the following points:

1. that the confidential information will only be disclosed on a "need to know" basis;

2. that the licensee will bind the third party to the same confidentiality provisions as the licensee has undertaken;

3. that the licensee may disclose to certain third parties without consent of the licensor; and

4. that the licensee may disclose to other third parties only with consent of the licensor.

Depending on the extent to which the licensee is required to disclose confidential information received from a licensor to third parties and depending on who such third parties are, a licensor may require that any disclosure to third parties may be made only after direct undertakings of confidentiality have been given by such third parties directly to the licensor.

From the point of view of the licensee, it is essential that the licensee secure in writing confirmation of the exceptions to the definition of "confidential information". In addition to the standard exceptions, where one is dealing with a number of owners who operate a tar sands plant through an operator, it is desirable that the licensee secure written confirmation that "confidential information" will not include any information independently developed by any employees of any of the owners of the project where such employees did not have actual knowledge of the confidential information disclosed by the licensor to the licensee. This is of particular importance where one is dealing with a company that 
has an extengive research program of its own, which is in effect operating independently of the personnel assigned to assist in the construction and completion of the tar sands plant.

Another concern from the point of view of the licensee is to ensure that the definition of licensor's "confidential information" clearly outlines the nature of the information which is to be disclosed by the licensor to the licensee, and also the period of time during which such information must have been developed by the licensor or acquired by the licensor for use by it and which it is free to disclose. In other words, a licensor will not wish to be under a continuing obligation to disclose its confidential information to the licensee for an unlimited period of time. The licensor will wish to include in the license agreement, as part of the definition of licensor's confidential information, the fact that such information must either have been developed by the licensor to the point where it would be useful in the commercial application of the process in question or be in its possession, and that the licensor has the right to disclose the same within certain specific time limitations.

\section{E. Grant Back}

While the licensee will wish to ensure that it receives the most up-to-date information from the licansor for as long a period as possible (particularly since such information will be of considerable use during the start-up period), the licensee must be aware that the licensor will require a grant back of the right to utilize the licensee's "confidential information". Therefore, in most instances, one will be in the position of endeavouring to determine which way the confidential information flow is most likely to occur. The licensee may wish to restrict the time limitations within which a mutual obligation to exchange information exists.

\section{F. The Most Favoured Licensee}

The licensee will prefer to secure from the licensor confirmation that, in the event that the licensor grants to a subsequent licensee more favourable treatment with respect to royalties, the licensor will in turn reduce the royalties payable by the licensee to the licensor. If the licensee has previously made all payments required to be made by reason of the licensor heving insisted on a lump sum paid-up license fee, then the agreement should provide for a refund of paid-up royalties.

\section{G. Hold Harmless}

One of the provisions which a licensee will wish to include in the license agreement is the hold harmless clause pursuant to which the licensor agrees to hold the licensee harmless against infringement of.third party patents or damages flowing from the use of the process. However, a licensee will ordinarily find that a licensor wishes to limit its liability in this regard to some portion of the paid-up royalty fee. In addition, the licensee should consider inserting in the process license agreement a provision that the royalty fees will terminate or be reduced in the event that it is later determined that a given patent is not valid. This provision would ordinarily be of more significance if the technology being licensed by the licensor were covered by a specific patent; however, with respect to licensing of tar sands technology, one will ordinarily find that the technical information received by the licensee from the licensor is of more significance than the patent rights granted by the licensor to the licensee.

\section{H. Process Guarantee}

It is worth noting that the licensee will never be in a position to secure from the licensor the type of guarantee or indemnity it requires in order to protect itself to any significant economic extent against potential losses by reeson of the failure of the process or the failure of the guarantees to meet the needs of the licensee. The process license fee to be paid by the licensee to the licensor will be relatively miniscule in most cases in relationship to reduced production losses. Consequently, licensors will wish to limit any potential exposure which such licensees may have to both special and indirect damages. 
Even though the damages to be paid by the licensor to the licensee can not possibly begin to compensate the licensee for its damages from reduced or non-existent production, the licensee wishes to ensure that such damages be significant enough that the licensor has some real incentive to correct the problems which have arisen by reason of the negligence or otherwise of the licensor. Therefore, in addition to the licensee securing from the licensor its agreement to provide certain technical asgistance at no additional charge, the licensee should alsa secure from the licensor some significant amount of damages in the event that the licensor fails to comply with its obligations under the license agreement.

The licensor will not, under any circumstances, wish to be responsible for any indirect or consequential damages. Also, it will wish to ensure that any guarantee it gives the licensee is based on the assumption that the guarantee only arises after the licensee has constructed and operated the units in accordance with the specifications of the licensor.

The guarantees offered by the licensor to the licensee will provide for a complicated system of test runs to determine whether or not the units meet the guarantees granted by the licensor. Unfortunately, from the point of view of the licensee, the licensor will usually insist on the opportunity for more than one test run in order to establish that the process is capable of producing the intended result. This will usually be objectionable to the licensee since the licensee will not ordinarily be able to afford the luxury of numerous "disruptions" caused by a number of test runs. Therefore, the licensee should endeavour to limit the number of test runs which the licensor may request in order to determine whether it has met its process guarantees.

\section{Engineering Services Agreement}

Even if the unit has a successful start-up and test runs establish its capabilities, it is advisable, if not indeed necessary, to have the right to call on the licensor's engineering expertise.

The engineering services agreement provides for access to such expertise, sets out the terms, including availability, compensation, responsibility and liability, etc.

This agreement also affords to the licensee access to the licensor's ongoing experience and knowledge relating to the licensed technology.

\section{J. The Stop-Out Agreement}

This agreement provides for a fixed maximum license fee for additional units of a certain capacity. The fee may be reduced as a concession from the licensor to a licensee where a process is new and untried.

In a pioneer commercial application of a process the licensee is obviously more at risk. The stop-out agreement recognizes that risk by providing a preferred license for future use of the process.

\section{THE TAR SANDS OPERATOR AS A DEVELOPER OF TECHNOLOGY}

By virtue of the construction and operation of a tar sands plant, the operator becomes a repository of a great deal of knowledge and information which, if properly protected, has value.

\section{A. Identification of Know-how and Trade Secrets}

The term "technology" can be used to encompass data, know-how and trade secrets. In a tar sands plant operation, a great deal of data, including numbers, records, reports, drawings and specifications are accumulated which may be of interest to a company just starting in the field. An example would be the maintenance records and costs for a centrifugal separator used in the plant. Know-how, which is defined as "practical knowledge of how to do something with smoothness and efficiency", may be of interest. An example would be the details of technique practised in mining a tar sand deposit with a dragline. Trade secrets may be charecterised as secret technical matters of substance. An example 
is the nature and quantity of addition of a particular chemical compound to the process to obtain improved results.

There is considerable overlap in the subject matter of "data", "know-how" and "trade secrets".

In any event, if this technology is protected and kept secret or confidential, it can provide the company with a valuable asset.

It should be kept in mind that, in order for a company to require an ex-employee or a licensee to keep something confidential, the following must be true:

1. the information involved must in fact be secret, that is, not generally known to the industry (two or more operators may know the same secret and this will not affect its capability of being the subject of confidentiality obligations); and

2. the disclosure must expressly or impliedly assume an obligation of confidentiality with respect to it.

\section{B. Protection of Technology}

In addition to being a purchaser of technology, Syncrude has, by virtue of constructing and operating its plant, become a developer of technology. Some of this technology is patentable.

Inventions are conceived by people. Syncrude employs many inventive people who are either inventors by design or by happenstance. It is therefore necessary to obtain from every new employee at the time of hiring an agreement with respect to confidential information, inventions and improvements.

\section{The Employee Secrecy Agreement}

The agreement provides that, in consideration of being hired by Syncrude, the employee agrees to four things:

1. that he will maintain in confidence and not disclose to others anything confidential that he has ascertained in the course of his employment;

2. that he will disclose to Syncrude in writing any invention or improvement made by him alone or in conjunction with others in the course of his employment with Syncrude, and will assign to the company all of his interest in such inventions or improvements;

3. that he discloses a list and description of all inventions made by him prior to his employment with Syncrude and which are agreed to be excluded from the terms of the agreement; and

4. that he agrees that all documents relating to the company's business are the property of the company. He undertakes not to copy the same or enable any third party to make copies of such documents, and agrees to surrender any such documents in his possession to Syncrude at the time of leaving the employ of the company.

It is important to obtain an agreement containing the above provisions from every employee at the time to his employment, in order to protect both the employee and the employer. The agreement provides for identification of prior inventions by the employee in which Syncrude has an opportunity to declare it has no interest. The employee may, however, have inventions in which Syncrude has considerable interest and which may be the very cause for the employment of such an individual. It is therefore necessary for Syncrude to have every employee, whether he is a technical person or otherwise, sign such an agreement because it not only relates to the employee's own inventiveness but to other information or material which may come into the employee's hands and which must remain confidential.

Some employees may invent things totally unrelated to Syncrude's main business. Syncrude's procedures provide for disclosure of such inventions and waiver of interest by the company.

Prior patents obtained by the employee are the property of the employee. However, the company by virtue of the agreement has a right to any inventions "made" by the em- 
ployee in the course of his employment with the company. This relates to inventions brought to a reasonable state of operativeness (either on paper or in concrete form) and of use to the company.

It is highly desirable to bring home to the employee that he is dealing with proprietary technology and that the employer expects him to treat it in a confidential way at all times. This is particularly the case with technical personnel and employees at the plant. Employees may be alerted to this by supplying them with written materials on the subject and reviewing it with them in groups. Pertinent company documents should also be marked confidential; and controls need to be applied with respect to entry into the plant.

\section{Contractors}

Another important area of protection of technology is contained in the confidentiality provision of agreements with consultants and contractors.

It is most important to establish ahead of time whether or not the results of a consultant or contractor's work for the operator is the property of the operator or the property of the contractor or consultant.

In some cases, the contractor is in the business of providing technical expertise and is reluctant to limit his ability to provide the same services to other companies. This, of course, must be recognized. In other cases the work may be related specifically to the operator's problem, and the operator wishes to have the benefit of any improvements to the plant and knowledge gained by utilizing the services of the contractors. It is also necessary to determine whether or not the charts, graphs, working papers, plans, etc. and the copyright pertaining thereto provided by various contractors is the property of the contractor or the company. Again there may be conflicting interest between the contractor and the company, and it is essential that ownership be identified in writing before the work is commenced.

In the license agreements entered into by Syncrude, there is commonly included the obligation to maintain the licensor's technology confidential. If a contractor is to have access to this technology, then a written obligation of confidentiality touching on this should be obtained from him. This obligation should extend to the contractor's employees, who may have an employee agreement binding them.

\section{E. Unsolicited Suggestions}

Another area of concern is unsolicited suggestions. There are enterprising people who are inventive not only in developing technology but also in holding up companies to ran$80 \mathrm{~m}$ for purported breaches or violations of trade secrets. The usual method is for such a person to approach a company, such as Syncrude, and put in the hands of the company a disclosure of his process or invention. The proffered information may disclose a process which the company already knows about. However, if the company has not documented its prior knowledge of the disclosed information, and if it in fact uses the process disclosed, the "inventor" may then bring an action against the company for breach of trust.

Syncrude has established a policy whereby all unsolicited suggestions received by any person in the company are directly forwarded to the Legal Services Department. Employees are instructed not to read the information disclosed or respond to the volunteer of the information. This is done possibly on the basis that the lawyer is the least likely person to understand the information. The material is then returned to the inventor with advice that the company does not wish to consider the merits of his invention unless it has received an executed disclosure and release agreement.

In some instances, if the tenderer of the information will undertake in writing that the disclosure forwarded is totally nonconfidential and comprises only a general description of the subject matter of his invention which is not proprietary, then the material will be reviewed and a decision taken as to whether or not the company wishes more information. At that time, an executed agreement would be required which may bind Syncrude to undertakings of confidentiality. 


\section{F. Gate Agreement}

It is also necessary to protect technology from being disclosed by inadvertence. For that reason, every visitor to the plant site during the construction period was required to sign a "gate agreement" wherein he undertook not to disclose any information which be gleaned by virtue of his physical presence at the site. In the operating phase, such an agreement is still required. This creates some concern, particularly with representatives of the media; but it is desirable in order to support the proposition that Syncrude's technology is proprietary.

\section{THE TAR SANDS OPERATOR AS THE SELLER OF TECHNOLOGY}

Syncrude as a company does not own technology nor sell it, nor does it act as the agent for its owners in the sale of the technology. The word "operator" is used in the sense of an owner-operator.

In spite of press accounts relating to the horrendous difficulties that Syncrude has encountered in starting up and operating its plant in the first year and a half of its operating life, Symcrude is now the operator of a plant which, through most of its component parts, has processed volumes of feed stock beyond the designed capacity of most of the units. There have been some notable areas of difficulty in the process; however, there is no doubt that the plant is capable of operating at and beyond the capacity for which it was designed. There will continue to be difficulties relating to efficiency in terms of making sure that the various component parts of the operation can produce at the capacity at which other parts can be operated; and ways and means of avoiding costly shut-downs because of failure of some component part must be developed. However, Syncrude now has a successful plant.

Much of the technology in the plant hes been purchased under license agreements or under technology exchange agreements. This third party information, of course, must be protected and segregated from knowledge and technology that has been generated by Syncrude. Presently, Syncrude is trying to determine what it has and what ability it has to assist the owners in marketing the technology.

Syncrude's owners are now in a position, potentially, of becoming the licensors of technology. In this new role they must determine what this thing is that they lnow.

\section{A. Technology Licensing}

\section{Some Items of Interest Respecting Technology Licensing}

As previously mentioned, proprietary "technology" is a label one can use to encompass plant data, know-how and trade secrets. The most common method of transferring this tochnology is by way of the grant of a license. When one begins to work for the first time on a license agreement, one encounters difficulties in derinition and needs to appreciate that proprietary technology has a finite life.

For example, it is normally difficult to define the bounds or scope of "know-how". One way to deal with this is to require the licensor to supply sufficient know-how so as to enable the licensee to accomplish the desired result. This leaves the extent of disclosure indeterminate but should lead to the desired outcome.

With respect to the finite life of technology, technology can become obsolete and secrets in some cases become known in the industry. For example, others conduct research in the same area; in spite of precautions, a certain amount of the technology becomes disseminated through disclosures by suppliers and ex-employees; and some of it must be published at government hearings and the like. Thus technology has a relatively short shelf-life and it behooves the owner to move it with alacrity if he seeks to earn income from it.

There is a further species of "tochnology" which has not yet been touched on. This is non-proprietary technology. There is much non-proprietary information readily available 
to other compenies through suppliers, government, service companies, consultants and the like. However, it is widely disseminated and, for a large project such as a tar sands plant, it would be very expensive to accumulate this information. However, it is accumulated in a company such as Syncrude which is already in the field. Presumably, it would pass from a licensor to the licensee. However, there may be reasons why one would want to try to separate proprietary from non-proprietary technology for purposes of the agreement. Significant problems of definition would arise if this were the case.

\section{B. Maintaining Secrecy of Technology}

As previously mentioned, to be subject matter capable of carrying an obligation of confidentiality, the item must be a secret, that is, it cannot be generally known or readily and legally available to the industry.

The old American case of Hamilton Mfg. Co. v. Tubbs Mfg. Co.' provides a comparison between the open way in which meny supposedly confidential operations are run and the guarded way in which the operation should be run if the principles of trade secrets and confidentiality are going to be relied on for protection.

The following seven precautionary practices should be considered and the appropriate ones applied if a company wishes to protect technology by what is known as trade secret law.

1. Anyone to whom the trade secret will be disclosed should, before the actual disclosure, sign an agreement to maintain the confidentiality.

2. All tangible trade secrets should be stamped with proprietary markings.

3. All trade secrets should be recorded and such records kept current.

4. Security messures should be specifically defined to ensure restricted access to the trade secret information.

5. Employees to whom the trade secrets are disclosed, or who will be developing trade secrets, should sign non-disclosure agreements, and their employment contracts might include a reasonable covenant not to compete.

6. All employees to whom trade secrets are disclosed should have a pre-disclosure interview and a written record maintained concerning the extent of their general knowledge with respect to the trade secret technology.

7. All employees terminating employment should be debriefed concerning the trade secret information.

Once the technology has been identified, protected and evaluated one is in the position of becoming a licensor, which brings us full circle. 


\title{
PART THREE
}

\author{
ELMA K. SPADY***
}

\section{THE ALBERTA OIL SANDS TECHNOLOGY AND RESEARCH AUTHORITY - AN APPROACH TO TECHNOLOGY HANDLING}

This section describes the function of a relatively new government agency which has been designed to assist industry and individuals in creating and recognizing new tochnology in a unique and specialized field. The "outcropping" of this venture - to coin a word which is familiar to those in the oil sands industry - is the sudden realization that the establishment of an agency devoted exclusively to research in oil sands and heavy oils requires lawyers working in this field to hone their skills in recognizing the new technology that will, of necessity, be created in order to meet the growing demands of a new industry. The "know-how" of the conventional a.: and gas industry will not be sufficient to develop the oil sands and, therefore, many steps along the way will be new. As lawyers, we must familiarize ourselves with a different set of skills in a field which has heretofore been the exclusive domain of patent lawyers in eastern Canada and the United States. There is perhaps no need for each of us to become proficient in the field of patent law: that is something we can leave to the specialist. But each of us should become aware that new technology is being developed around us, and we should have the ability to recognize and deal with it.

This section discusses the role undertaken by the Alberta Oil Sands Technology and Research Authority in creating and assisting in the development of new technical methods in fundamental and advanced research, and in the economic development of oil sands, heavy oils and the enhanced recovery of conventional oils. It is hoped that the reader will see how this agency may be of assistance in helping oil and gas lawyers make themselves aware of the potential existence of new technology in their own offices.

\section{A. The Establishment of the Alberta Oil Sands Technology and Research Authority (AOSTRA)}

On June 6, 1974, the Alberta Government assented to a new enactment establishing a specially created Crown corporation designed to provide means whereby

(a) research into the technological methods required for the efficient and economic recovery and processing of crude bitumen and other oil sands products from oil sands deposits in Alberta may be assisted, encouraged and promoted. ...

This premise was contained in the "purpose" clause of Bill 47, entitled The Oil Sands Technology and Research Authority Act, which is now the statute that embodies the structure and organization of the Alberta Oil Sands Technology and Research Authority (AOSTRA).

In addition to this primary provision to assist, encourage and promote basic oil sands research, there were three secondary purposes relating to environmental, university-oriented and synthetic crude oil product research. A fourth purpose, which has taken on added significance as time passes, provides that ${ }^{3}$

(c) the compilation, assessment and dissemination of present and future technological information relating to the exploration for, recovery and processing of oil sands products.... may be achieved.

Until the establishment of AOSTRA, all basic and applied oil sands research was performed by the oil industry, mainly in its research laboratories outside Canada, by other commercial research organizations, by universities, and by the Research Council of Alberta on behalf of the Alberta Government. The creation of AOSTRA has not limited

-. General Counsel. Alberta Oil Sands Technulugy and Research Authurity. Edmuntun. Alberta.

2. The Oil Sands Technulugy and Research Authority Act. S.A. 1974, c. 47, s. 2(a).

3. Id., s. 2(c). 
the research being performed by these organizations; neither has it supplanted the vast research and technology networks developed by the oil industry, and other commercial organizations, or the basic research of the Universities and the Research Council. However, it has been designed to meet the need for specialized emphasis on technology in a field where concentration is required at this time in our energy-conscious economy. Since 1974, the organization has grown to meet the need for specialized research into heavy oil problems' and into new methods for the enhanced recovery of conventional oils.

While the above paragraph sets forth the general philosophy of AOSTRA, there are at least four basic or fundamental policies which AOSTRA has adopted in the pursuit of this philosophy.

\section{B. AOSTRA Policy Considerations}

The first policy AOSTRA has adopted is based on the recognition that existing commercial projects attack specific situations that are related to specific geographical and geological areas. For example, the Syncrude and Suncor projects are located on sites where the overburden can largely be stripped, laying bare the resource beneath; but more research is needed to develop a technology for the recovery of the more extensive deeply buried oil sands. In situ technology for reservoirs having an overburden of greater than 500 metres is the only alternative in developing the huge deposits in the Athabasca, Cold Lake, Peace River and Wabasca areas where stripping technology cannot logically be em. ployed. Therefore, the development of technology for the recovery of oil sands in all types of reservoirs must be encouraged and promoted because it is apparent that a single process will not be suitable for all situations.

Directly related to the encouragement of these new kinds of technologies is the second of AOSTRA's policies: the realization that more than one industrial partner will be required to finance a future commercial venture. AOSTRA therefore attempts to promote cooperation among companies at the technology research and development level, with a view to ultimately facilitating the early commercialization of oil sands operations in as many diverse areas as possible.

Related to the first two policies is a third, that the development of the technology in these areas is so crucial that its direction should come from some central source. This leads to the fourth policy - avoiding duplication of effort to develop new technolosy, and acting as a clearing house for the dissemination of that technology to ensure that it is put into the market place at the most opportune moment.

\section{Five Years of Experience}

In the first five years of AOSTRA's operations, it has become increasingly apparent that AOSTRA may become the central repository for oil sands and related technology developed in Alberta or developed elsewhere and brought to Alberta. AOSTRA is there to encourage the development of oil sands and related technologies, both basic and applied, through funding, direct participation and indirect involvement. Its function is to gather the technology, to assess it, to request further work be performed with a view to perfecting it, and to disseminate it both in and out of the Province to all potential users at a fair market value. AOSTRA sees its role as a monitor as well: it can steer a researcher into areas he himself may not have perceived or direct him to solve a particular problem apparent to AOSTRA and its industry partners but not apparent to him. The policy of avoiding duplication of effort in research may be AOSTRA's greatest service to industry and to the public. What AOSTRA hopes to offer is a dedication to the principle that oil sands and related technology development will be ready and available when and as it is required. This has to be a fundamental objective because of the fifteen to twenty year time lag between the conception of an idea and its commercial application.

\footnotetext{
4. S.A. 1975 (2), c. $28,38.2$ and 3.
}

5. S.A. 1979, c. 57, ss. 2 and 3. 


\section{New Mandate}

Therefore, a question arises: should a government agency intervene in technology development which normally takes place in industry as relevant problems are encountered in the field? A government agency should not enter into direct competition with industry but should assist financially and technically in an effort to encourage industry to undertake technology development earlier than it might if left to its own devices. In 1979, for example, intervention in a certain aspect of the conventional oil and gas industry was considered by government to be warranted, and AOSTRA's mandate was enlarged to include the undertaking of research into developing new enhanced recovery methods for conventional oils. With approximately 21 billion barrels of crude oil remaining in the ground and only $5 \%$ to $20 \%$ of the oil remaining in the so-called "depleted" reservoirs capable of economic recovery with current technology, there is a necessity for the encouragement of technology development in that field.

\section{E. Providing Leadership and Direction}

While intervention in technology development is important, it is perhaps more vital for government to promote the concept of leadership in directing this development. The position taken by AOSTRA is that duplication of effort in developing technology may be the greatest detriment to advancement in the long run. Government, it would appear, has to direct individual and corporate inventors to those problems which require solutions. Otherwise, a concept of "high-grading" develops, and in an energy deficient world, this situation cannot be tolerated.

Therefore, a novel concept developed by industry will be examined by AOSTRA and, if found unique and plausible, will be funded in whole or in part. The resulting information that is developed will be owned by AOSTRA and kept confidential, but will be made available to any third party at fair market value. (Such technology will normally be made available to the industry partner and its affiliates on a world-wide, royalty free basis.) By participating on a joint financial basis with industry, however, technology is under the. control of a central agency like AOSTRA but is available to all who desire its use. What is important is that the technology is being developed and placed in a central repository in an orderly fashion as opposed to perhaps being unavailable and having to be re-invented or duplicated by more than one member of the industry.

It is also important to place a monetary value on tochnology. Many governments have learned, to their chagrin, that the free dissemination of important technology results in its ultimate devaluation. A good example is one country's scheme to promote the enhanced recovery of "depleted" conventional oil reservoirs. A program is designed to encourage testing of novel schemes but one of the requirements is the dissemination of technology without restrictions on confidentiality. Therefore, those members of the oil industry who develop novel schemes in enhanced recovery are reluctant to reveal them to the Government because of this lack of confidentiality. So the industry now develops the technology on its own, and duplication of effort talses place. It may appear from the foregoing that AOSTRA places most of its focus on preventing the duplication of effort in research. This is not the case. An important part of AOSTRA's philosophy is based on receiving equivalent value for money invested in technology development in order to keep the system honest. AOSTRA has a public mandate, and must protect the taxpayers' investment by receiving a dollar's worth of technology for a dollar spent on its development. Realistically, this is not possible, as many dollars need to be invested in basic research before the real problems can be attacked. Therefore, some duplication may be warranted. This is especially true in our university projects where costs are relatively low. In contract research funded by AOSTRA, an application from a very competent researcher may require modification to meet a specific need. Because the researcher may not be familiar with all of the ramifications of what is requested, he will be given every opportunity to acquaint himself with work done by other researchers, industry projects in which AOSTRA is participating, the literature, patent searches, etc. 
The same guidance is often needed in the very expensive in situ and upgrading projects. If a particular problem arises and AOSTRA is aware of a potential solution in another project, AOSTRA will suggest to the consortium that some arrangement be made for gaining access to the pertinent technology. There is thus an opportunity for an ongoing "trade-off" among our partners. AOSTRA feels this is a very efficient system of developing and exchanging technology for economic reasons, and also because it involves a liaison or interface between researchers and industry which would not exist if each worked independently. This also assists in developing a broad research base from which many projects may "take off".

\section{F. Types of Research}

It is not proposed to discuss the various projects in which AOSTRA is involved at length but it might be interesting to note that we are involved in eight in situ type projects with one more on the horizon, eight upgrading and related projects, and approximately thirty-five active university projects. We have established access agreements to enable industry and universities to work together and have encouraged the employment of university researchers on industry projects and vice verse.

Another area which deserves discussion is AOSTRA's role as an owner and licensor of oil sands, heavy oil and enhanced recovery technology. Appendix A displays the basic principles of AOSTRA technology ownership and licensing in in situ projects, which principles, in the main, apply to all projects.

In our in situ projects, AOSTRA supplies $50 \%$ of project financing and owns $100 \%$ of the technology generated. Depending on the circumstances, AOSTRA may purchase the previously created technology as well; but it always obtains the exclusive licensing rights for the two technologies in combination with each other in Canada. A typical technology agreement is included as Appendix B. Note the manner in which licensing income is normally distributed, the confidentiality requirements and the disclosure principles.

In the extraction and upgrading projects, AOSTRA often initially supplies $100 \%$ of the funding for basic research and usually owns the technology generated. Ownership of the technology depends entirely on whether a new technology is created or whether an existing tochnology is applied to an oil sands or heavy oil feedstock. In the latter case, AOSTRA usually supplies only a portion of the funding and the industry participant retains control of the existing technology. This presents an opportunity for the lawyer to engage in some highly imaginative drafting, as both parties strive to attain equity in a relationship where ownership rights are, on occasion, difficult to determine in the first instance, and in the second instance, may be hard to regulate in that erosion of ownership may have to be tolerated if one wants a share of ultimate licensing income. AOSTRA, however, gains the right to sell the results of the experiment in an attempt to encourage industry participation for a full-scale demonstration and ultimately fully commercial venture. Licensing rights are normally exclusive to AOSTRA in Canada with emphasis on oil sands and heavy oil processing, with the industry partner retaining other rights in Canada. Outside Canada, licensing rights in extraction and upgrading technology are often shared in oil sands and heavy oil processing applications, with the industry partner generally retaining other rights of application. Regardless of who acts as the licensing agent, the income from technology sales is shared equitably between AOSTRA and industry.

In the case of the university projects, AOSTRA supplies $100 \%$ of the funding and owns all technology generated. Licensing is exclusive to AOSTRA in all applications. Researchers are given liberal publishing rights but there is a confidentiality period of one year which can be reduced to six months to facilitate university publishing conventions. An access program has been developed to allow industry to participate in a series of selected university projects at a minimal cost.

AOSTRA also receives applications for funding from individual inventors. In such cases, the content of the application naturally determines the nature and extent of the 
rights accruing to each party in the final agreement. Often, these kinds of applications are nothing more than "paper inventions" which may require a great deal of basic investigation before a viable project can be undertaken. If, however, the background work has been diligent and the "invention" appears worthwhile pursuing, AOSTRA may assist the inventor. in finding a research facility to conduct further research and may provide a portion or all of the necessary funding. To allow the inventor to share in any rewards arising from the application of his invention in a future commercial venture, a deemed value will be ascribed to the invention and that value is then used as the base ingredient of a revenue-sharing formula.

Depending upon the ability of the inventor to participate in the resulting project, and after the Authority has expended what it considers to be sufficient funds for the purpose of assessing the commerciality of the invention, AOSTRA may require assignment of the invention to itself. If the research conducted fails to confirm the viability of the inven. tion, it will be re-assigned to the inventor so that he may pursue other alternatives. If the research is successful, AOSTRA may retain ownership of the invention, and the inventor will receive a percentage royalty from AOSTRA's future licensing efforts based on the revenue-sharing formula.

\section{APPENDIX A}

\section{PRINCIPLES OF TECHNOLOGY OWNERSHIP RIGHTS CONTAINED IN AOSTRA/INDUSTRY IN-SITU AGREEMENTS}

1. AOSTRA obtains patents and owns all new technology.

2. AOSTRA is the sole licensing agent for new technology in Canada.

3. AOSTRA and the company can both license outside Canada.

4. Regardless of who grants a license, licensing income is divided in proportion to the financial contributions to the project.

5. AOSTRA contributes $50 \%$ of the money and has $50 \%$ of the management control. (50\% was chosen rather than $49 \%$ or $51 \%$, to avoid one party having complete control; provisions for breaking deadlocks are included.)

6. AOSTRA agrees to keep information confidential, but must be able to license to any third party at a fair market value fee. The fee will be established by agreement with the company, and failing agreement, by arbitration.

7. AOSTRA can include a company's prior technology as necessary to complete its licensing package. (This prevents the old technology from being a block to licensing the new technology.) The company's expenditures for prior technology are recognized in distributing the licensing income.

8. AOSTRA, Alberta government agencies (including Crown Corporations), a limited number of industrial parties to the agreement and their affiliates, have the right to use project technology (including patents) without payment of any licensing fees. All others must pay a license fee.

9. AOSTRA can place its technical representatives in the company's office at project expense. The prime function of these individuals is to acquire project technology and to assemble it in the form suitable for AOSTRA to license to third parties.

10. AOSTRA and the company jointly own all project's physical assets and share all revenue including salvage value of assets, proceeds from the sale of products, etc. 


\section{APPENDLX B}

\section{EXTRACTS FROM A TECHNOLOGY AGREEMENT}

2. This Technology Agreement is entered into for the purposes of defining the assignment, ownership, use, disclosure, licensing and license-fee sharing rights and obligations of the Parties with respect to technical information and inventions;

NOW THEREFORE THIS AGREEMENT WITNESSETH that in accordance with Article 14 of the Project Agreement and in consideration of the mutual covenants set forth herein and in the Project Agreement to be performed and observed, the Parties hereto covenant and agree each with the other as follows:

\section{ARTICLE 1 CONCURRENT AGREEMENTS}

\subsection{Coincidental Lives of Agreements}

This Technology Agreement and the Project Agreement executed concurrently herewith are to operate together during the coincidental lives of the two agreements and for such time thereafter as may be provided in this Technology Agreement. Both agreements are to be interpreted each in the light of the other so as to avoid conflict between the two, provided however, that if the terms of this Technology Agreement conflict with the terms of the Project Agreement, the terms of this Technology Agreement shall govern. Notwithstanding the foregoing, this Technology Agreement shall not expire or terminate because the Project Afreement has expired or terminated.

\subsection{Project Agreement Definitions To Apply}

Unless otherwise provided, all definitions of terms given in the Project Agreement 'shall apply for purposes of this Technology Agreement where such terms are capitalized herein.

\section{ARTICLE 2}

\section{ADDITIONAL DEFINITIONS}

For purposes of this Technology Agreement, the following terms shall have the following meanings:

2.01 "Affiliate" means:

(a) a company controlling, directly or indirectly, the majority of the voting stock of a Participant;

(b) a company, the majority of the voting stock of which is controlled, directly or indirectly, by a Participant;

(c) a company, the majority of the voting stock of which is controlled, directly or indirectly, by a company or companies which control, directly or indirectly, the majority of the voting stock of a Participant;

at the Effective Date.

Affiliate also means a company which would be an Affiliate provided that on or after the Effective Date, the acquisition of control of, or the creation of, the company in ques. tion is a bona fide acquisition or creation and is not an acquisition or creation which is in any manner intended to result in a reduction of the Authority's licensing income under this Technology Agreement. In the event of dispute as to whether or not the company is an Affiliate, the Authority or the Participants may initiate arbitration in accordance with Article 10 hereof to decide the question.

An Affiliate ceases to be an Affiliate at the time that the control as described above in Clauses (a), (b), and (c) terminates, provided that in such event the Authority, in so far as it is capable of so doing, shall license the company ceasing to be an Affiliate as a Licensee pursuant to this Technology Agreement. 
2.02 "Effective Date" means the date this Technology Agreement is executed by the last of the Authority and the Participants.

2.03 "technical information", as it is used herein, without limiting the generality of such an expression, includes: lonow-how, procedures, combinations of steps, and process and apparatus designs; research, geological, reservoir, injection, production, monitoring, product, product treating, equipment, maintenance and economic data; and reports, studies, specifications, drawings, computer programs, documents, evaluations, analyses, interpretations and calculations.

2.04 "Prior Technical Information" means all technical information in existence and owned or controlled by any of the Participants or their respective Affiliates as of the Effective Date and which relates to the Program to be carried out in the Project.

2.05 "Prior Patents" means all patent rights owned or controlled by any of the Participants or any of their respective Affiliates as of the Effective Date, and which relate to inventions directly used in connection with the Project.

2.06 "Project Technical Information" means all novel technical information embodied in or generated in connection with the Project at Project expense and includes all technical information generated at joint cost pursuant to Article 6.15 of the Project Agreement.

2.07 "Project Inventions" means all inventions generated in connection with the Project at Project expense. Project Inventions includes all inventions

(a) conceived at Project expense in connection with the Project by any Party's employees, contractors or agents, except those contractor's inventions exempted pursuant to Article 7.15 of the Project Agreement; or

(b) conceived as a result of exposure to Project information and developed at Project expense.

Project Inventions also includes all inventions generated at joint cost pursuant to Article 6.15 of the Project Afreement.

2.08 "Licensee" means a third party granted a license and/or immunity from suit pursuant to this Technology Agreement permitting use of technical information and/or inventions licensable hereunder in return for a fair market value license fee or a cross-license.

2.09 "Phase" means Phase A or Phase B as defined in the Project Agreement, and "Phases" means both Phase A and Phase B, as defined in the Project Agreement.

2.10 "Prior Copyrights" means all copyrights now owned or controlled by any of the Participants or any of their respective Affiliates in copyright works generated prior to the Effective Date and which are used in connection with the Project.

2.11 "Project Copyrights" means all copyrights in copyright works generated in connection with the Project at Project expense, and all copyrights in copyright works generated at joint cost pursuant to Article 6.15 of the Project Agreement.

2.12 "Alberta Government agencies" shall be interpreted to include Alberta Crown corporations.

2.13 Where the phrase "make available" is used in Article 4.01, it shall be taken to include the following arrangements with respect to the supply of technical information:

(a) a detailed description of the technical information involved and the form in which it is available shall be supplied to the Authority;

(b) the Authority shall then be entitled at any time during the term hereof to request in writing that described portions or all of the technical information be supplied to it;

(c) said requested technical information shall then promptly be supplied to the Authority.

2.14 "Prior Technology" means and includes Prior Technical Information. Prior Patents and Prior Copyrights.

2.15 "Project Technology" means and includes Project Technical Information, Project Inventions and Project Copyrights. 


\section{ARTICLE 3 TERM}

3.01 This Technology Agreement shall commence on the Effective Date and, except as provided herein, shall end on the 35th anniversary of the Effective Date, unless continued thereafter with the mutual consent of the Authority and the Participents.

\section{ARTICLE 4 \\ PRIOR TECHNICAL INFORMATION}

\subsection{Participants to Make Available - Authority Use Rights}

The Participants shall promptly and without charge make available to the Authority the Prior Technical Information. The Participants hereby grant to the Authority a license fee-free world-wide immunity from suit by any of the Participants or their respective Affiliates for experimental use by the Authority of the Prior Technical Information, together with the right to extend such immunity to the Authority's agents and contractors for use only in connection with the Authority's experimental operations.

\subsection{Obligation of Confidentiality on Authority}

Subject to Articles 4.03 to 4.07 inclusive, the Authority shall keep confidential all Prior Technical Information and any other technical information made available to it by the Participants.

\subsection{Authority Confidential Disclosure to Associated Group}

The Authority is entitled to disclose Prior Technical Information to its agents and contractors, and to Alberta Government agencies and departments, provided that each of said recipients agrees in writing to keep such technical information confidential. Alberta Government agencies and departments shall be entitled to disclose on a confidential need-to-know basis Prior Technical Information in conjunction with any part of Project Technical Information to others to the extent necessary for the design, engineering, construction, operation and maintenance of the facilities of said agencies and departments using the Project Technical Information, and such others shall be entitled to use such technical information but only to assist in the design, engineering, construction, opera. tion and maintenance of said facilities.

\subsection{Authority Confidential Disclosure to Potential Licensees}

The Participants hereby grant to the Authority an immunity from suit by each of them or their respective Affiliates for disclosing Prior Technical Information in conjunction with any part of Project Technical Information to any potential licensee on a limited non-confidential "look-see" basis to enable said potential licensee to decide whether to enter negotiations for a license under this Technology Agreement.

\subsection{Authority Disclosing to Licensees}

The Authority is entitled to disclose Prior Technical Information in conjunction with any part of Project Technical Information to its Licensees, provided that each such Licensee agrees beforehand in writing to keep such technical information confidential. The Authority may permit the Licensee to disclose on a confidential need-to-know basis Prior Technical Information in conjunction with any part of Project Technical Information to others to the extent necessary for the design, engineering, construction, operation, and maintenance of the facilities of said Licensee. The Authority may further permit such others to use such technical information but only to assist in the design, engineering, construction, operation and maintenance of said facilities.

\subsection{Authority Granting Use Rights to Associated Groups}

The Participants hereby grant to the Authority the right to extend, on a license fee-free world-wide basis, to its agents, its contractors, and Alberta Government agencies and departments, an immunity from suit by any of the Participants or any of their 
respective Affiliates for use of Prior Technical Information in connection with the opera. tions.

\subsection{Authority Granting Use Rights to Licensees}

The Participants hereby grant to the Authority the right to extend, on a world-wide basis, to each of its Licensees an immunity from suit by any of the Participants or any of their respective Affiliates for use of Prior Technical Information in conjunction with Project Technical Information in connection with their operations.

\subsection{Right to Use Prior Copyrights}

Whenever there is a right hereunder to use Prior Technical Information it includes a right to use and copy works in which Prior Copyrights subsist.

\section{ARTICLE 5 \\ PRIOR PATENT RIGHTS}

5.01 The Participants bereby grant to the Authority a license fee-free, world-wide immunity from suit by any of the Participants or any of their respective Affiliates for infringement of any Prior Patents when the inventions covered by the Prior Patents are used in conjunction with Project Technical Information, together with the right to extent such immunity to

(a) the Authority's agents and contractors for use only in connection with the Authority's operations;

(b) Alberta Government agencies and departments; and

(c) the Authority's Licensees.

\section{ARTICLE 6 \\ WARRANTY AND REPRESENTATION}

6.01 Each of the Participants warrants and represents that it has exercised its best efforts, prior to the Effective Date, to acquire from its relevant Affiliates the capacity to grant the rights to disclose and use, and the immunities from suit, with respect to all Prior Technical Information and Prior Patents. It further warrants and represents that it has advised the Authority in writing, prior to the date of execution hereof, of any significant part of said Prior Technical Information or Prior Patents to which it was unable to acquire the capacity as aforesaid.

6.02 Each of the Participants warrants and represents that, to the best of its knowledge, the Project, as presently designed and conceived, shall not incorporate apparatus or processes which are:

(a) protected by way of confidential disclosure; and

(b) owned or controlled by any of the Participants or any of their respective Affiliates; and

(c) rot subject matter or inventions within the meaning of Prior Technical Information or Prior Patents.

\section{ARTICLE 7 \\ AUTHORITY - PROJECT TECHNOLOGY}

\subsection{Ownership}

The Authority owns all Project Technology arising from the Phase or Phases in which it participates and, except as permitted in this Technology Agreement, no one other than the authority shall have the right to use, copy or disclose the Project Technology.

\subsection{Obligation of Confidentiality on Authority}

The Authority shall keep confidential all Project Technical Information, except as is required to be disclosed in patenting Project Inventions. 


\subsection{Authority Confidential Disclosure to Associated Group and Licensees}

Notwithstanding Article 7.02, the Authority has the right to disclose Project Technical Information to its agents, contractors and Licensees, and to Alberta Government agencies and departments, provided that each of said recipients agrees in writing to keep such technical information confidential. Licensees and Alberta Government agencies and departments shall be entitled to disclose on a confidential need-to-know basis such Project Technical Information to others to the extent necessary for the design, engineering, construction, operation and maintenance of the facilities of said agencies and departments and Licensees using that Project Technical Information, and such others shall be entitled to use such technical information but only to assist in the design, engineering, construction, operation and maintenance of said facilities.

\subsection{Authority and Associated Group Right to Use}

The Authority and Alberta Government agencies and departments shall have the right to use the Project Technology without accounting therefor to the Participants. The Authority may permit its agents and contractors to use Project Technology, but only in connection with the Authority's operations. Where the Authority or an Alberta Government agency or department owns an interest in a company utilizing Project Technology in a commercial facility, then such company shall be required to pay a partial license fee in accordance with the appropriate example in Schedule 1.

\subsection{Authority Disclosure to Potential Licensees}

Notwithstanding Article 7.02, the Authority has the right to disclose any part of Project Technical Information to any potential licensee on a limited non-confidential "look-see" basis to enable said potential licensee to decide whether to enter negotiations for a license pursuant to this Technology Afreement.

\subsection{Authority Granting Use Rights to Licensees}

In accordance with Article 9, the Authority may permit its Licensees to use Project Technolozy.

\subsection{Right to Use Copyrights}

Whenever there is a right hereunder to use Project Technical Information, it shall include a right to copy works in which Project Copyrights subsist.

\section{ARTICLE 8 \\ PARTICIPANTS - PROJECT TECHNOLOGY}

\subsection{Participants' Access to Information and Right To Extend to Affiliates}

Subject to Articles 8.02 and 14.01, each Participant shall have access to and a license fee-free, non-exclusive, world-wide license to use the Project Technology from the Phase or Phases in which it participates, together with the right to extend this license to its Affiliates.

\subsection{Confidentiality Obligation On Participants}

Subject to Articles 8.03 to 8.10 inclusive, and to Article 16.03, each Participant agrees to keep confidential all Project Technical Information acquired by it.

\subsection{Right to Confidentially Disclose to Affiliates}

In conjunction with the right of extension under Article 8.01, and notwithstanding Article 8.02, each Participant has the right to disclose Project Technical Information acquired under Article 8.01 to its Affiliates, provided that each Affiliate receiving such technical information agrees in writing to keep such technical information confidential. 


\subsection{Right to Participants and Affiliates to Use}

Each Participant and each of its Affiliates has the right to use the Project Technology acquired pursuant to Article 8.01.

\subsection{Commercial Facilities Involving a Third Party}

(a) If a Participant or any of its Affiliates have been extended rights to use Project Technology under Article 8.01, and if such Participant or any of its Affiliates use Project Technology in a commercial facility owned by a joint venture or other combination involving one or more third parties (except the third party company referred to in paragraphs (b) and (c) hereof), then the third party shall be required to pay a license fee in accordance with the appropriate example in Schedule " 1 ".

(b) If a company, which is not an Affiliate but in which one or more of the Participants or their Affiliates, together with one or more third parties, own an interest therein, uses Project Technology in a commercial facility which said company owns, then said company shall be required to pay a license fee in accordance with the appropriate example in Schedule " 1 ".

(c) In the event that a commercial facility, as described in paragraphs (a) or (b) of this Article 8.05 is to be operated, the Authority, under Article 9.01, or the Company or the Authority, as the case may be, under Article 9.02, shall license the one or more third parties in said joint venture or other combination, or said company, as the case may be, at a fair market value license fee in accordance with the principles illustrated in Schedule "1" attached hereto, thereby to enable Project Technology to be used in said facility.

(d) None of the Participants or their Affiliates shall sell or otherwise assign an intereat in an Afriliate to a third party company for the purpose of enabling that company to thereby participate through said Affiliate in a commercial facility using Project Technology and avoid taking a license hereunder from the Authority or the Company or paying a fair market value license fee pursuant to this Technology Agreement. In the event of a dispute as to the purpose of the sale or assignment the Authority or the relevant Participant may initiate arbitration in accordance with Article 10 hereunder to decide the question.

\subsection{Company and Affiliates Disclosing to Potential Licensees}

Notwithstanding Article 8.02, the Company and its Affiliates shall each have the right to disclose any part of the Project Technical Information to a potential licensee on a limited non-confidential "look-see" basis to enable said potential licensee to decide whether to enter negotiations for a license for use of the technical information outside Canada.

\subsection{Company and Affiliates Disclosing to Licensees}

Notwithstanding Article 8.02, the Company and its Affiliates shall each have the right to disclose Project Technical Information to a Licensee for use in a licensed operation outside Canada, provided that such Licensee agrees beforehand in writing to keep such technical information confidential, and to use it only in connection with that operation.

\subsection{Company and Affiliates Granting Use Rights to Licensees}

The Company and its Affiliates shall each have the right, exclusive except as to the Authority, to extend to a Licensee an immunity from suit by the Authority for patent infringement for use of Project Inventions in a licensed operation outside Canada, or for use of Project Technical Information in a licensed operation outside Canada.

\subsection{Confidential Disclosure Right for Facility}

Notwithstanding Article 8.02, the Company, its Affiliates and their respective Licensees, and each other Participant and its Affiliates shall have the right to disclose on a confidential need-to-lnow basis Project Technical Information to others to the extent necessary for the design, engineering, construction, operation and maintenance of the operations of their respective facilities, and such other shall be entitled to use such tech- 
nical information for such purposes but only in connection with the pertinent discloser's facilities.

\subsection{Disclosure to Banks and Governments}

Notwithstanding Article 8.02, the Company, its Affiliates, the Authority and their respective Licensees and each other Participant and its Affiliates shall have the right to disclose Project Technical Information to any governmental agency which requires such disclosure pursuant to legislation or regulations made under legislation, or to a bank, financial institution or insurance company from which it is seeking financing or insurance, provided said institution or company agrees beforehand in writing to keep such technical information confidential, and further provided that it shall exercise its best efforts to obtain agreement from said governmental agency to keep such technical information confidential.

\section{ARTICLE 9 \\ LICENSING}

\subsection{Licensing Rights in Canada}

As owner of the Project Technology as provided in Article 7.01, and as a result of the rights granted to the Authority by the Participants in respect to Prior Technology pursuant to this Technology Agreement, the Authority has the exclusive right to license any third party to use in Canada:

(1) any part of Project Technology; and

(2) any part of Project Technology in combination with any part of Prior Technology.

The Authority agrees to negotiate in good faith with any bona fide third party requesting a license pursuant to this Technology Agreement.

\subsection{Licensing Rights Outside Canada}

The Company, its Affiliates and the Authority each has the right, to the exclusion of all other Parties, to license any third party to use outside Canada:

(1) any part of Project Technology; and

(2) any part of Project Technology in combination with any part of Prior Technology.

\subsection{Cross Licensing}

Notwithstanding Article 9.04, a licensor hereunder may license a third party under Articles 9.01 and 9.02 in consideration of a cross-license, provided that all of the Parties have previously agreed to such arrangement and to the terms pertaining thereto.

\subsection{Setting License Fee}

Fair market value shall be determined by the Authority and the Company in respect to the licensing rights anticipated to be licensed under Articles 9.01 and 9.02, and the Company and the Authority shall consult before the license to such Licensee is granted to determine what the fair market value license fee shall be, and the portion of the said fee to be allocated to Phase A technology and to Phase B technology which shall be determined as provided for in Article 9.07. If such fair market value cannot be agreed upon at any stage prior to such licenses being granted, either the Company or the Authority may initiate arbitration pursuant to Article $\mathbf{1 0}$ in order to determine such fair market value. Once fair market value is determined by arbitration the respective licensors of such licensing rights shall grant the licenses at the fair market value license fee so determined. If subsequent to such determination, the Company and the Authority are unable to grant a license at such value the Company and the Authority may agree on a license fee lower than that value, and if such fee cannot be agreed upon, the matter may be re-submitted to arbitration for determination of a lower license fee. 


\subsection{Cooperation in Preparing Licensing Materials}

(a) The Company agrees to assist the Authority, on reasonable terms to be agreed upon, to develop satisfactory licensing materials, including but not limited to all the design specifications, capital and operating costs and operating correlations needed to provide a potential licensee with knowledge of the benefits and reliability of the technology being offered for license. Monies paid to the Company by the Authority in respect to any costs incurred in developing such licensing materials shall be considered a licensing cost of the Authority.

(b) The Authority agrees to assist the Company, on reasonable terms to be agreed upon, to develop satisfactory licensing materials, including but not limited to all the design specifications, capital and operating costs and operating correlations needed to provide a potential licensee with knowledge of the benefits and reliability of the technology being offered for license. Monies paid to the Authority for any costs incurred in developing such licensing materials shall be considered a licensing cost of the Company.

\subsection{Licensing Costs}

The licensor hereunder shall initially pay all licensing costs, including those associatod with preparing licensing materials, contacting potential licensees, negotiating licenses, and providing services to the Licensees. Licensing costs shall be deemed to be a charge on licensing income as provided for in Article 9.07.

\subsection{Recovering Costs and Splitting License Income}

After deducting the licensing costs referred to in Articles 9.06, 11.02 and 11.04, if any, from licensing fees earned in respect to the licensing of the rights referred to in the whole of this Article 9, the remainder of such license fees earned (referred to as "the increment"), shall be divided between the Parties in accordance with the following formulae:

(1) where the increment relates to licensing of Phase A technology, each Party's share of the increment shall equal

$$
\frac{A}{B} \times C
$$

where $\quad A=$ the Party's required contribution, expressed in dollars, excluding contributions required to be made on behalf of a Defaulting Party, to the Phase A Project Expenditures up to the end of Phase A;
B = the Phase A Project Expenditures up to the end of Phase A;
C = the Phase A increment available for distribution.

(2) where the increment relates to the licensing of Phase $B$ technology and where a Party has participated in. Phase B, such Party's share of each increment shall equal

$\begin{array}{ll}\frac{D}{E} \times F & \\ D & =\quad \begin{array}{l}\text { each Party's required contribution, expressed in dollars, } \\ \text { excluding contributions required to be made on behalf } \\ \text { of a Defaulting Party to the Phase B Project } \\ \text { Expenditures up to the end of Phase B; }\end{array} \\ \text { the Phase B Project Expenditures up to the end of } & \begin{array}{l}\text { Phase B; } \\ \text { the Phase B increment available for distribution. }\end{array}\end{array}$

(3) where the increment results from licensing of a combination of Phase $A$ and Phase B technologies, the amount of $C$ and $F$ respectively, for application in clauses (1) and (2) above shall be determined as follows:

and

$$
C+F=\text { the total increment }
$$




$$
\frac{\mathrm{C}}{\mathrm{F}}=\frac{\mathrm{B}}{\mathrm{E}}
$$

Where the costs referred to in the first paragraph of this Article 9.07 are reimbursed to whichever of the Company or the Authority incurs them, such reimbursement shall be done on a basis proportional to the costs outstanding to each of the Authority and the Company at the time of division of the increment until such costs have been fully reim. bursed.

The increment shall be divided on a quarter yearly basis and each Party's share shall be paid to it within sixty $(60)$ days after the end of each quarter of each calendar year in which the increment is received.

\subsection{Books, Accounts and Records}

The Company, and the Authority shall keep true and correct books, accounts and records of licensing revenues, patent costs and licensing costs and shall furnish copies of same to each other promptly upon request. In addition, any Party may at its sole cost, risk and expense inspect and examine during the term of this Technology Agreement, and for 12 months thereafter, in the Company's, and the Authority's offices, all books, accounts and records relating to the above costs and revenue. Any discrepancies or disputes resulting therefrom or relating thereto which cannot be resolved between either the Company or the Authority and the other Party will be settled by arbitration in accordance with Article 10.

\subsection{Licensee's Access to Site}

Upon reasonable notice from a licensor to the Operator, a Licensee is entitled to have access at its own risk and expense to the Site and the operations thereon to observe licensed subject matter in operation, provided however that such visits shall not unreasonably interfere with said operations.

\subsection{Notice of Contact with Potential Licensee}

If either of the Company or the Authority have commenced negotiations with a potential licensee outside Canada for a license hereunder, the negotiating Party shall promptly so advise the other Party in writing. The Company and the Authority shall then agree as to which Party will continue to negotiate with the potential licensee and failing agreement the original negotiating Party shall continue the negotiations and the other Party shall have the right to have a representative attend the negotiations.

\subsection{Participants Dealing With Prior Technology}

Nothing contained in this Agreement shall in any way limit or restrict a Participant from dealing as it sees fit, as a licensor or otherwise, with the Prior Technical Information it has made available to the Authority pursuant to Article 4.01 except that in respect to such dealings the Participant will preserve the rights granted to the Authority under that Article.

\section{ARTICLE 10 ARBITRATION}

10.01 Upon the written request of either the Authority or a Participant to effect arbitration, the Parties concerned shall meet and attempt to appoint a single arbitrator. If they are unable to agree on a single arbitrator within twenty (20) days of the request, then upon written demand of either of them and within ten (10) days of such demand, each of them shall name an arbitrator and the two arbitrators so named shall promptly choose a third. If either of them shall fail to name an arbitrator within ten (10) days from such demand, then the second arbitrator shall, upon application by such of them as shall have named an arbitrator, be appointed by any Justice of the Trial Division of the Alberta Court of Queen's Bench. If the two arbitrators shall fail within ten (10) days from their appointment to agree upon and appoint the third arbitrator, then upon written ap- 
plication by either of them the third arbitrator shall be appointed by any other Justice of the Trial Division of the Alberta Court of Queen's Bench.

10.02 The single arbitrator or the arbitrators so chosen shall proceed immediately to hear and determine the question or questions in dispute. The decision of the single arbitrator shall be made within forty-five (45) days after his appointment, subject to any reasonable delay due to unforseen circumstances. The decision of the arbitrators, or a majority of them, shall be made within forty-five (45) days after the appointment of the third arbitrator, subject to any reasonable delay due to unforseen circumstances. Notwithstanding the foregoing, in the event the single arbitrator fails to make a decision within sixty (60) days after his appointment, or if the arbitrators, or a majority of them fail to make a decision within sixty $(60)$ days after the appointment of the third arbitrator, then either of the said Parties may elect to have a new single arbitrator or arbitrators chosen in like manner as if none had previously been selected.

10.03 The decision of the single arbitrator or the decision of the arbitrators, or a majority of them, shall be drawn up in writing and signed by the single arbitrator or by the arbitrators, or a majority of them, and shall be final and binding upon all Parties to this Tochnology Agreement as to any question or questions so submitted to arbitration, and the Parties shall be bound by such decision and perform the terms and conditions thereof.

The compensation and expenses of the single arbitrator or the arbitrators shall be apportioned equally between the Parties concerned in the arbitration or unless otherwise determined by the arbitrators.

\section{ARTICLE 11 \\ OBTAINING PATENTS}

\subsection{Authority to Select}

The Authority has the first right and responsibility to select the Project Inventions to be patented and to prepare, file and prosecute the patent applications and to obtain and maintain all patents issued on the selected Project Inventions.

\subsection{Authority to Pay}

The Authority shall pay all costs incurred in connection with preparing, filing, obtaining and maintaining patents on the Project Inventions which it elects to patent.

\subsection{Filing of Patent Applications}

Within ninety (90) days of being notified of a Project Invention pursuant to Article 7.12 of the Project Agreement, the Authority shall notify the Participants whether or not it will file patent applications on said invention in any particular country or at all. If within said ninety $(90)$ days the Authority does not notify the Participants of its intent to file such patent application, then the Participants, or any one of them, if they wish to obtain patent protection in respect to such Project Invention in such country, shall so notify the Authority in writing. The Authority is then entitled for a period of thirty (30) days following the Company's said notice, to elect, by notice in writing to the Participants, to file a patent application in the Authority's name in that country, in which event the Authority is obligated to proceed with such filing. In the event that the Authority does not so elect to file, the Participants, or any of them, are entitled to file in the Authority's name a patent application for the particular Project Invention for the country in question and shall assign all right, title and interest in said patent application to the Authority and to obtain and maintain such patent.

\subsection{Participants to Pay}

The Participant or Participants making the patent application shall pay all costs incurred in connection with preparing, filing, obtaining and maintaining patents on the Project Inventions for which it or they file in accordance with Article 11.03. 


\subsection{Authority to Keep Participants Advised}

The Authority shall supply the Participants with copies of the patent specifications as filed by it and issued, and shall consult with the Participants when requested to do so to keep them informed as to the progress and status of the patent protection.

\subsection{Participants to Keep Authority Advised}

The Participant or Participants making the patent application shall supply the Authority with copies of the patent specifications as filed by it or them and issued, and shall consult with the Authority when requested to do 80 to keep it informed as to the progress and status of the patent protection.

\subsection{Participants' and Authority's Further Rights}

With respect to patents and patent applications filed by one or more Participants in the Authority's name pursuant to Article 11.03, the Participants shall have, in addition to the rights granted in Article 8, and notwithstanding the provisions of Article 9.07, the right to extend use rights to others for purposes other than those related to oil sands and heavy oils use, without accounting therefor to the Authority. Similarly, the Authority is not required to account to the Participants for use by the Authority, together with the right to extend such use rights to others, for purposes other than those related to oil sands and heavy oils use, with respect to patents and patent applications filed by the Participants in the Authority's name pursuant to Article 11.03.

\section{ARTICLE 12 \\ COMMERCIAL TECHNOLOGY}

\subsection{To Be Made Available to Each Participant}

If a Participant is a Participating Party in Phase A and Phase B, (and such Participant is not a Defaulting Party in such Phases pursuant to Article 14.01) the Authority shall provide to the Participant, and the Participant in turn shall have the right to provide to its Affiliates, all technical information and inventions generated in connection with or arising out of the design, engineering, construction and operation of any facilities either owned or licensed by the Authority, owned by any Alberta Government agencies or departments or any of the Authority's Licensees using the Project Technology on a commercial basis, but limited to that part or parts of the said facilities which incorporate licensed subject matter, for the first five (5) years of operation of each of such facilities. The rights of the Participants set forth in the preceding sentence shall continue for the term of this Technology Agreement.

\subsection{Authority Granting Use Rights to Each Participant}

The Authority hereby grants to each Participant a non-exclusive, license fee-free, irrevocable, world-wide right to use the commercial technology made available to the Participants under Article 12.01, together with the right to extend such right to their Affiliates.

\subsection{To Be Made Available to Authority}

If the Authority is a Participating Party in Phase A and Phase B, (and is not a Defaulting Party in such Phases pursuant to Article 14.02), each Participant shall have the right to provide to Alberta Government agencies and departments and to the Authority's Licensees, all technical information and inventions generated in connection with or arising out of the design, engineering, construction and operation of any facilities in which any of the Participants and their Affiliates, or the Company's Licensees, own an interest, and in which the Project Technology is used on a commercial basis, but limited to that part or parts of the said facilities which incorporate licensed subject matter, for the first five (5) years of operation of each of such facilities. The rights of the Authority sot forth in the preceding sentence shall continue for the term of this Technology Agreement. 


\subsection{Participants Granting Use Rights to Authority}

Each Participant grants to the Authority a license fee-free, irrevocable, world-wide right to use the commercial technology made available to the Authority under Article 12.03, together with the right to extend such right to Alberta Government agencies and departments and to its Licensees.

\subsection{Parties to Keep Confidential}

The Authority and the Participants shall keep confidential the technical information provided each other under the provisions of Articles 12.01 and 12.03, provided however that each of them has the right to disclose such technical information under the same conditions as each has in respect to Project Technical Information.

\subsection{Authority to Provide Access to Facilities}

The Authority shall provide an access right to the Participants, which the Participants in turn shall have the right to extend to their Affiliates, to the facilities referred to in Article 12.01, during the first five (5) years of operation of each of such facilities, upon the giving of reasonable notice of each visit, for the purpose of observing the operation of the portions of said facilities embodying commercial technology, provided such access does not unreasonably interfere with the operation of said facilities.

\subsection{Participants to Provide Access to Facilities}

Each Participant shall provide an access right to the Authority, which the Authority in turn shall have the right to extend to Alberta Government agencies and departments and to its Licensees, to the facilities referred to in Article 12.03, during the first five (5) years of operation of each of such facilities, upon the giving of reasonable notice of each visit, for the purpose of observing the operation of the portions of said facilities embodying commercial technology, provided such access does not unreasonably interfere with the operation of said facilities.

\subsection{No Guarantees or Liability}

The rights granted to the Parties under this Article 12 are not to be interpreted by the recipient party to carry with them any guarantees as to the accuracy, completeness or reliability thereof, and the grantor shall not be liable for any consequential damages from the rights granted under this Article 12.

\section{SCHEDULE " 1 "}

\section{Attached to and forming part of this} TECHNOLOGY AGREEMENT

\section{EXAMPLES OF LICENSE FEE CALCULATIONS}

\section{Basic Principle}

Third parties are required to pay a full fair market value license fee for their use, directly or indirectly, of Project Technical Information and Project Inventions in a com. mercial facility. If a Participant or its Affiliate combine with one or more third parties to use said tochnology through the vehicle of a joint venture, other combination or company, then such joint venture, other combination or company would not be required to pay a full license fee, but only a percentage of that fee equal to the third party's participation in said joint venture, combination or company. 


\section{Examples of Mechanics of Determining License Fees}

(Assume a full license fee would bo $\$ 1,000$ )

Example 1. Assume a commercial operation comprising only third parties.

Third parties only

Fee $=100 \%$ of $\$ 1,000=\$ 1,000$ Total License Fee $=\$ 1,000$

Example 2. Assume a commercial operation with a Participant or its Affiliate with a $12 \frac{1}{2} \%$ or greater Participation Percentage and a third party.

Participant (or Affiliate) with $60 \%$ interest

Fee $=0$

Third Party with $40 \%$ interest

Fee $=\$ 1,000 \times .4=\$ 400$

Total Fee $=\$ 400$ 